\title{
Regulation of haemopoietic stem-cell proliferation in mice carrying the $\mathrm{Si}^{\mathrm{j}}$ allele
}

\author{
R. E. Ploemacher, P. G. J. Nikkels, W. J. Molendijk, N. H. C. Brons and \\ K. G. M. Brockbank
}

Department of Cell Biology and Genetics, Erasmus University, Rotterdam, The Netherlands

(Received 12 July 1983; revision accepted 6 November 1983)

\begin{abstract}
We investigated a haemopoietic stromal defect, in mice heterozygous for the $\mathrm{Sl}^{\mathrm{j}}$ allele, during haemopoietic stress induced by treatment with bacterial lipopolysaccharides (LPS) or lethal total body irradiation (TBI) and bone-marrow cell (BMC) reconstitution. Both treatments resulted in a comparable haemopoietic stem cell (CFU-s) proliferation in $\mathrm{Sl}^{3} /+$ and $+/+$ haemopoietic organs. There was no difference in committed haemopoietic progenitor cell (BFU-e and CFU-G/M) kinetics after TBI and $+/+$ bone-marrow transplantation in $\mathrm{Sl}^{\mathrm{j}} /+$ and $+/+$ mice. The $\mathrm{Sl}^{\mathrm{j}} /+$ mice were deficient in their ability to support macroscopic spleen colony formation ( $65 \%$ of $+/+$ controls) as measured at 7 and 10 days after BMC transplantation. However, the $\mathrm{Sl}^{\mathrm{j}} /+$ spleen colonies contained the same number of BFU-E and CFU-G/M as colonies from $+/+$ spleens, while their CFU-s content was increased. On day 10 post-transplantation, the macroscopic 'missing' colonies could be detected at the microscopic level. These small colonies contained far fewer CFU-s than the macroscopic detectable colonies. Analysis of CFU-s proliferation-inducing activities in control and post-LPS sera revealed that $\mathrm{Sl}^{\mathrm{j}} /+$ mice are normal in their ability to produce and to respond to humoral stem-cell regulators.

We postulate that $\mathrm{Sl}^{\mathrm{l}} /+$ mice have a normal number of splenic stromal 'niches' for colony formation. However, $35 \%$ of these niches is defective in its proliferative support.
\end{abstract}

The Sl${ }^{j}$ allele has been demonstrated to have effects upon haemopoiesis in homozygous fetuses (Cole et al., 1974), and in allophenic mice (Mintz \& Cronmiller, 1978). Adult mice, heterozygous for the $\mathrm{Sl}^{j}$ allele, are haematologically characterized by a mild normochromic macrocytic anaemia and a quantitative deficiency of haemopoietic stem cells (CFU-s), early erythroid progenitors (BFU-e) and granulocyte/macrophage progenitors (CFU-G/M) (Ploemacher \& Brons, 1984; Brockback \& Ploemacher, 1983). When $\mathrm{Sl}^{\mathrm{j}} /+$ mice are used as recipients for the CFU-s assay $30 \%$ fewer macroscopic spleen colonies are formed than in normal $+/+$ controls, and this deficiency is not due to defective CFU-s lodgment in the spleen (Ploemacher \& Brons, 1984). Furthermore, ectopically implanted $\mathrm{Sl}^{\mathrm{j}} /+$ spleens support less

Correspondence: Dr R. E. Ploemacher, Department of Cell Biology and Genetics, Faculteit der Geneeskunde, Erasmus Universiteit, Rotterdam, The Netherlands. 
CFU-s than $+1+$ spleens (Ploemacher \& Brons, 1984). These observations led us to propose that there is a defective microenvironmental support for colony formation in the $\mathrm{Sl}^{\mathrm{j}} /+$ spleen.

The spleen in normal adult mice responds to bacterial lipopolysaccharide (LPS) treatment with a large burst of haemopoietic activity at 4-7 days later (McCulloch et al., 1970; Vos, Buurman \& Ploemacher, 1972). It has been reported that the severely anaemic Sl/Sld mice are not able to support the extensive splenic CFU-s accumulation observed in normal littermates upon LPS injection (Ploemacher et al., 1983a) or to sustain CFU-s proliferation following lethal total body irradiation (TBI) and bone-marrow transplantation (McCulloch et al., 1965). Production of humoral regulators of CFU-s proliferation, i.e. stem-cell activating factors (SAF; Dicke, van den Engh \& Lowenberg, 1974; Cerny, Warner \& Rubin, 1975; Löwenberg \& Dicke, 1977) and splenic haemopoiesis stimulating factor (SHSF, Staber \& Metcalf, 1970), in response to LPS treatment, was normal in $\mathrm{Sl} / \mathrm{Sl}^{\mathrm{d}}$ mice (Ploemacher et al., 1983a). The failure of $\mathrm{Sl} / \mathrm{Sl}^{\mathrm{d}}$ mice to respond to bacterial LPS was attributed to a refractory response of these mice to humoral regulators of CFU-s proliferation.

In this investigation we have studied the ability of $\mathrm{Sl} /+$ mice to support proliferation of haemopoietic stem cells and progenitor cells in haemopoietic stress situations and analysed their ability to produce and to respond to humoral regulators of CFU-s proliferation.

\section{MATERIALS AND METHODS}

\section{Animals}

Strain 129 and $\mathrm{SvSl}^{\mathrm{j}} \mathrm{CP}$ mice of both sexes were bred at the Laboratory Animals Centre of the Erasmus University, Rotterdam. The origins of maintenance conditions of these mice have been described (Ploemacher \& Brons, 1984).

\section{Assays for in vivo colony formation and progenitor cell growth}

A Gammacell $40{ }^{137}$ Caesium Irradiation unit (Atomic Energy of Canada Ltd, Ottawa) was used at a dose rate of $1.3 \mathrm{~Gy} / \mathrm{min}$. The CFU-s assay of Till \& McCulloch (1961) was performed using 8.5 Gy total body irradiated $\mathrm{Sl}^{\mathrm{j}} /+$ and $+1+$ mice as recipients. Growth kinetics of progenitor cells were determined according to the retransplantation method of Siminovitch, Till \& McCulloch 1964). Briefly, $5 \times 10^{6}$ femoral bone-marrow cells (BMC) from pools of three $+/+$ mice were injected intravenously (i.v.) into three or four intermediate recipients with $\mathrm{Sl}^{\mathrm{j}} /+$ or $+/+$ gene complements. At days 4,7 and 10 these mice were killed, their spleens and femurs removed and single cell suspensions prepared. The CFU-s content of the suspensions was determined using the in vivo spleen colony assay while BFU-e and CFU-G/M were quantified in vitro in a semi-solid medium as previously described (Brockbank \& Ploemacher, 1983). Diameters of surface colonies on spleens fixed in Bouin Hollande's fluid were estimated in tenths of a $\mathrm{mm}$, using an inverted microscope and a fine-scale transparent matrix.

In order to determine the CFU-s distribution among macroscopic spleen colonies, $1 \times 10^{4}$ nucleated $+/+\mathrm{BMC}$ were injected i.v. into lethally irradiated $+/+$ and $\mathrm{Sl}^{\mathrm{j}} /+$ mice to give about two macroscopic colonies in any one $+/+$ spleen and about one in $\mathrm{Sl}^{j} /+$ spleens. Ten days later, individual colonies were dissected out of the spleen and assayed for their content of CFU-s. A logarithmic conversion of the data was used in calculating the mean colony CFU-s content to correct for the skewed distribution of CFU-s among the colonies (Siminovitch et al., 1964). Spleen parts that were free of colonies on gross inspection were also assayed for their CFU-s content. 


\section{Preparation of post-LPS serum and normal serum}

Mice were injected intraperitoneally (i.p.) with $500 \mu \mathrm{g}$ of Salmonella typhosa lipopolysaccharide (prepared according to Westphal) in a buffered saline solution (BSS) or with BSS alone. Six hr later, cardiac blood was obtained by a sterile procedure and clotting was allowed for $1 \mathrm{hr}$ at room temperature. After storage at $4^{\circ} \mathrm{C}$ overnight, the post-lipopolysaccharide serum (PLPSS) and normal mouse serum (NMS) were collected by two consecutive centrifugations at $500 \mathrm{~g}$ and stored at $-20^{\circ} \mathrm{C}$ until use. The level of residual endotoxin in the sera was estimated in the Limulus lysate assay as described by Levin et al. (1970).

\section{Detection system for stem-cell activating factor (SAF) and splenic haemopoiesis stimulating factor (SHSF)}

The assay used to detect SAF is based on the prolonged maintenance of proliferating CFU-s in suspension culture, as compared to quiescent CFU-s (Dicke et al., 1974; Cerny et al., 1975; Löwenberg \& Dicke, 1977). SAF was detected by the assay of Wagemaker, Merchav \& Burger (1982). SAF (Concanavalin-A-stimulated mouse spleen conditioned medium, MSCM stage III), purified by affinity chromatography, gel filtration and ion exchange chromatography using DEAE-sepharose at $\mathrm{pH} 8 \cdot 0$, was a gift from $\mathrm{Dr}$ G. Wagemaker, Rijswijk, the Netherlands. These procedures increased the specific activity to about 82,000 -fold and the preparation contained approximately $40 \%$ of the SAF activity of the original MSCM. Duplicate cultures of $6 \times 10^{5}$ nucleated bone-marrow cells (BMC) were incubated for 4 days in a volume of $1 \mathrm{ml}$ in loosely capped plastic tubes (Falcon No. 2057) at $37^{\circ} \mathrm{C}$ and an atmosphere of $5 \% \mathrm{CO}_{2}$ in air. The medium consisted of $\alpha$ medium, supplemented with $0.25 \mathrm{w} / \mathrm{v}$ delipidated BSA (Sigma), $4 \times 10^{-6} \mathrm{M}$ human transferrin-2Fe (Behringwerke), $10^{-7} \mathrm{M} \mathrm{Na}_{2} \mathrm{SeO}_{3}$ (Koch Light), $10^{-4} \mathrm{M} \beta$-mercaptoethanol (Merck), $10^{-6} \mathrm{M}$ isoproterenol (Sigma), $10^{-6} \mathrm{M}$ hydrocortisone-hemisuccinate (Sigma), $10^{-3} \mathrm{~g} / 1$ nucleosides (adenosine, cytosine, guanine, uridine, thymidine, $2^{\prime}$ deoxyguanosine, $2^{\prime}$ deoxyadenosine and $2^{\prime}$-deoxycytosine) and $1.125 \times 10^{-5} \mathrm{M}$ cholesterol (Calbiochem).

The serum content (Staber \& Metcalf, 1980) of splenic haemopoiesis stimulating factor (SHSF) was quantified in vivo by measurement of the splenic CFU-s accumulation at 4 days after i.p. injection of $0.3 \mathrm{ml}$ serum.

\section{RESULTS}

Growth characteristics of haemopoietic precursors in lethally irradiated $\mathrm{SP} /+$ and $+/+$ mice Figure 1 shows the cellularity of spleen and femur in $\mathrm{Sl}^{\mathrm{j}} /+$ and $+/+$ mice on days 4,7 and 10 following lethal whole body irradiation and i.v. injection of $5 \times 10^{6}+1+$ BMC. Between days 4 and 10 , the growth of $+/+\mathrm{BMC}_{\text {in }} \mathrm{Sl}^{\mathrm{j}} /+$ organs was essentially the same as in $+/+$ organs when measured by the organ cellularity. Normal values for unirradiated animals showed a slightly reduced femoral cellularity in $\mathrm{Sl}^{\mathrm{j}} /+$ mice, in agreement with previously published findings (Ploemacher \& Brons, 1984).

It appears that the growth of CFU-s, BFU-e and CFU-G/M is essentially the same in $\mathrm{Sl}^{\mathrm{j}} /+$ and $+/+$ organs (Fig. 2), despite the fact that $\mathrm{Sl}^{\mathrm{j}} /+$ mice showed a reduced spleen colony formation when injected with the proper number of BMC (Table 1). When the CFU-s growth data is expressed as a percentage of normal organ CFU-s content (Fig. 3), the growth of $+/+$ BMC-derived CFU-s is noticeably well supported in $S l^{j} /+$ spleen and femurs. The same can be concluded for the growth kinetics of BFU-e and CFU-G/M (not indicated in figures).

Injection of $4 \times 10^{4}+/+B M C$ into $\mathrm{Sl}^{j} /+$ mice led to a diminished spleen colony 
Fig. 1. Growth curve of $+/+$ BMC in the spleen $(\triangle, \Delta)$ and femurs $(O, O)$ of $\mathrm{Sl}^{\mathrm{j}+}(\mathrm{O}, \Delta)$ and $+1+(O, \Delta)$ mice. At day $0,5 \times 10^{6} \mathrm{BMC}$ were injected i.v. The arithmetic mean ( \pm s.e.m.) of nine individually assayed mice in three separate experiments are given.

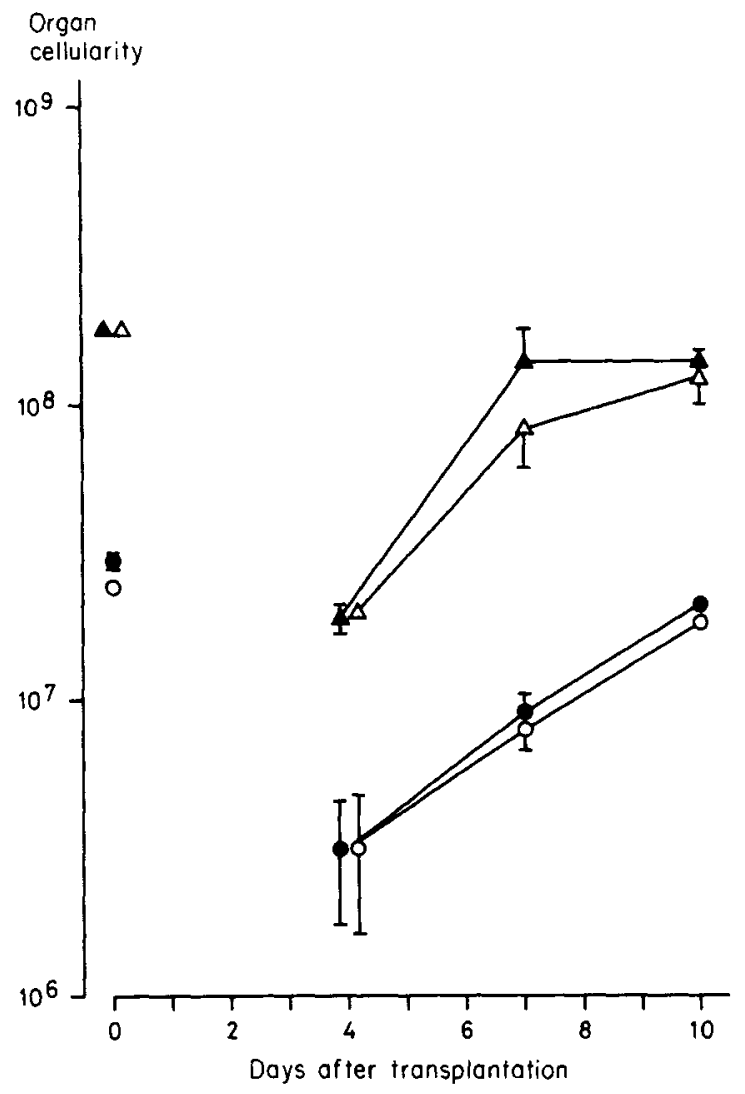

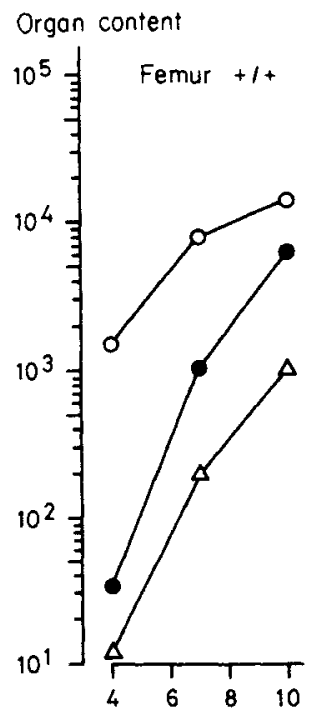
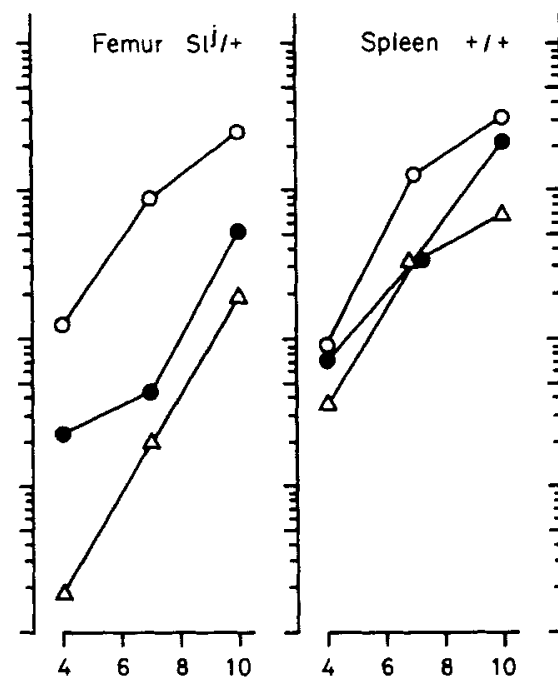

Spleen $5 i^{j}+$

Days after transplantation

Fig. 2. Growth curve for CFU-s $(\triangle)$, BFU-e $(O)$ and CFU-G/M $(O)$ in the femur and spleens of $\mathrm{SI}^{\mathrm{j}} /+$ and $+1+$ mice. At day $0,5 \times 10^{6}+/+$ BMC were injected i.v. Presented are the arithmetic means of three separate experiments to which a total of nine mice contributed. 


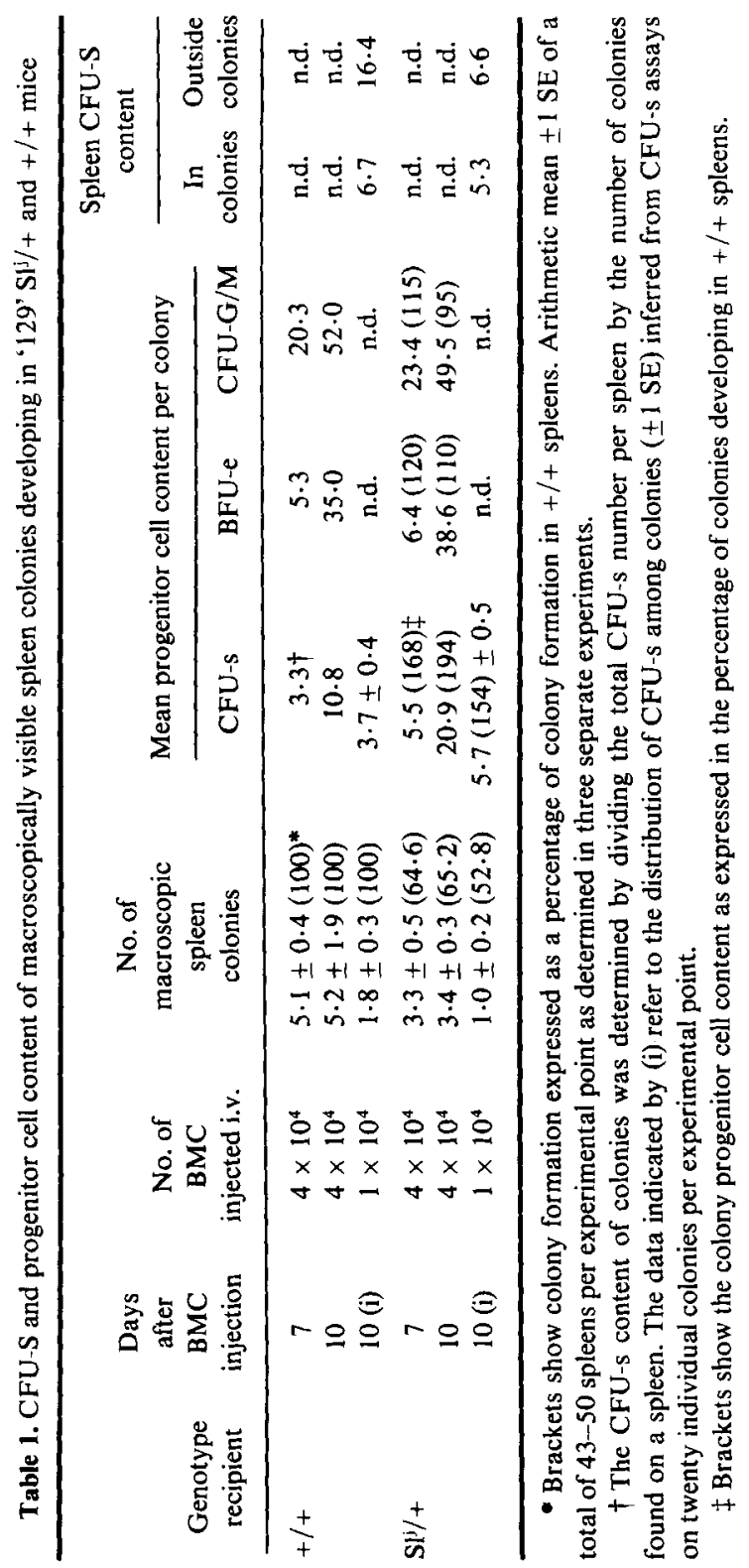


Fig. 3. Growth curve for $+1+\mathrm{CFU}-\mathrm{s}$ in the spleen $(\Delta, \Delta)$ and femurs $(\mathrm{O}, \mathrm{O})$ of $\mathrm{Si} /+(\mathrm{O}, \Delta)$ and $+/+(\mathbf{O}, \mathbf{\Delta})$ mice. Analysis as for Fig. 2.

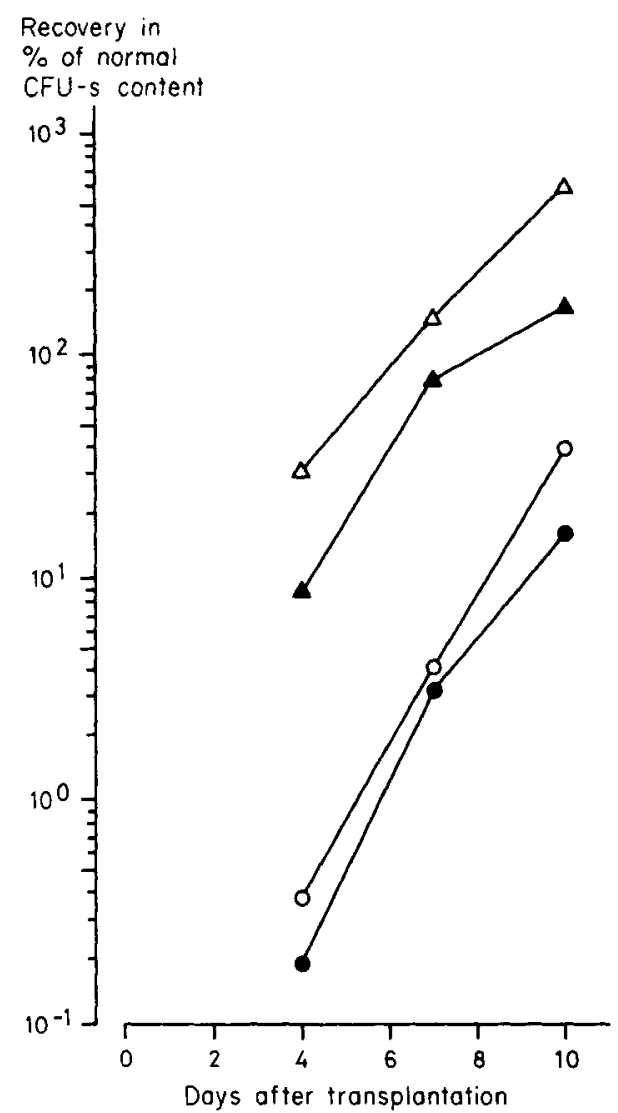

formation as compared to that in $+1+$ spleens (Table 1). The size of the $\mathrm{Sl}^{\mathrm{j}} /+$ spleen colonies on day 7 (not indicated in table) was not significantly different from colonies found on $+1+$ spleens, as estimated by measurement of the diameter of the four largest surface colonies per spleen. Colonies on $\mathrm{Sl}^{\mathrm{j}} /+$ spleens had a mean diameter $( \pm 1 \mathrm{SE})$ of $1.03 \pm 0.03 \mathrm{~mm}$, while $+/+$ colonies measured $1.12 \pm 0.03 \mathrm{~mm}$. BFU-e and CFU-G/M numbers in individual days 7 and 10 colonies were the same in $\mathrm{Sl}^{\mathrm{J}} /+$ spleens as in $+/+$ spleens; however, consistently higher CFU-s numbers were observed in $\mathrm{Sl}^{\mathrm{j}} /+$ colonies (Table 1). From Table 1 it would also appear that at least half of the CFU-s contained in any spleen on day 10 is not found within macroscopic spleen colonies, but is localized in parts of the spleen in which no colonies could be detected on gross inspection.

Microscopic inspection revealed a decrease of the day 7 microscopic colony formation in $\mathrm{Sl}^{J} /+$ spleens, apparent on gross inspection of the spleen. At 10 days the number of macroscopically detectable colonies in $\mathrm{Sl}^{\mathrm{j}} /+$ spleens was $53-65 \%$ of the colony formation in $+/+$ spleens, whereas no reduction of microscopic colonies was noticed (Table 2). This observation indicates that the development of the 'missing' colonies had been delayed to such an extent that their size was too small to meet the limits for their detection on the spleen surface. If all CFU-s that were retrieved from parts of the spleen that did not contain colonies on gross inspection (Table 1) were contained in microscopic colonies (Table 2), then $\mathrm{Sl}^{\mathrm{j}} /+$ mice would have a lower CFU-s content of their microscopic spleen colonies, as compared to $+/+$ mice. 
Table 2. Types of haemopoietic colonies as detected in $\mathrm{Sl}^{\mathrm{l} /}+$ and $+/+$ spleens at 7 and 10 days after irradiation

( $8.5 \mathrm{~Gy})$ and grafting of $3 \times 10^{4}+/+$ bone-marrow cells

\begin{tabular}{|c|c|c|c|c|c|c|c|c|c|c|}
\hline \multirow{2}{*}{$\begin{array}{l}\text { Recipient } \\
\text { genotype }\end{array}$} & \multirow{2}{*}{$\begin{array}{c}\text { Day of } \\
\text { observation }\end{array}$} & \multirow{2}{*}{$\begin{array}{l}\text { No. of } \\
\text { mice }\end{array}$} & \multicolumn{2}{|c|}{ Colonies/spleen $(1+\mathrm{SE})$} & \multicolumn{6}{|c|}{$\begin{array}{c}\text { Percentages of different histologic types } \\
\text { of colonies }\end{array}$} \\
\hline & & & Macroscopic & Microscopic & EI & EII & EIII & $\mathrm{G}$ & $\mathbf{M}$ & $\mathrm{U}+\mathbf{M i x}$ \\
\hline$+/+$ & 7 & 65 & $5.14(0.20) \dagger$ & $6.61(0.27)$ & $24 \cdot 2$ & $33 \cdot 4$ & $23 \cdot 1$ & $2 \cdot 3$ & $2 \cdot 8$ & $14 \cdot 1$ \\
\hline $\mathrm{Sl}^{1} /+$ & 7 & 61 & $3.28(0.11)$ & $4.55(0.09)$ & 20.4 & 37.8 & $23 \cdot 0$ & $3 \cdot 0$ & $1 \cdot 5$ & 14.4 \\
\hline$+1+$ & 10 & 61 & $4.08(0.27)$ & $5.44(0.15)$ & 9.9 & $41 \cdot 3$ & $14 \cdot 1$ & $15 \cdot 0$ & $4 \cdot 2$ & $15 \cdot 5$ \\
\hline $\mathrm{Sl}^{\mathrm{j}} /+$ & 10 & 62 & $2.90(0.13)$ & $5.47(0.35)$ & 9.9 & $41 \cdot 0$ & $14 \cdot 6$ & 11.4 & 7.9 & $15 \cdot 5$ \\
\hline
\end{tabular}

* Abbreviations for the colony types are: EI, erythrocytic colonies containing less than $20 \%$ normoblasts; EII, between 20 and $80 \%$ normoblasts; EIII, more than $80 \%$ normoblasts; G, granulocytic, M, megakaryocytic; $\mathrm{U}+\mathrm{Mix}$, undifferentiated + mixed type.

$\dagger$ All figures represent means $( \pm 1 \mathrm{SE})$ of data collected in four separate experiments.

\section{CFU-s proliferation in the spleen following LPS-W injection}

Groups of three to four mice were injected i.v. with various doses of LPS-W and analysed 4 days later. The $+/+$ mice reached a plateau level of splenic CFU-s and cellularity at $30 \mu \mathrm{g}$ LPS-W, indicating that this dose already maximally stimulated CFU-s proliferation in the spleen within this time period (Table 3 ). $\mathrm{Sl}^{\mathrm{j}} /+$ mice, which normally have only $35-40 \%$ of the

Table 3. CFU-s accumulation in the spleen of $129 \mathrm{SP}^{3} /+$ and $+/+$ mice 4 days after lipopolysaccharide injection

\begin{tabular}{|c|c|c|c|c|}
\hline \multirow{2}{*}{$\begin{array}{c}\text { Dose } \\
\text { of } \\
\operatorname{LPS}(\mu \mathrm{g})^{*}\end{array}$} & \multicolumn{2}{|c|}{ CFU-s } & \multicolumn{2}{|c|}{ Cellularity $\left(\times 10^{7}\right)$} \\
\hline & $+1+$ & $\mathrm{Sl}^{\mathrm{j}} /+$ & $+1+$ & $\mathrm{Sl}^{\mathrm{j}} /+$ \\
\hline 0 & $4013(185) \dagger$ & $1535(437)$ & $17.5(1.0) \ddagger$ & $15 \cdot 3(0.6)$ \\
\hline 30 & $37,158(1673)$ & $23,555(4060)$ & $28.9(0.9)$ & $25.4(0.9)$ \\
\hline 100 & $35,389(6546)$ & $35,137(3716)$ & $30 \cdot 9(1 \cdot 2)$ & $27.5(1.0)$ \\
\hline 300 & $41,196(6349)$ & $15,803(4112)$ & $27.9(2 \cdot 6)$ & $24 \cdot 8(2 \cdot 3)$ \\
\hline
\end{tabular}

- LPS-W from Salmonella typhosa.

$\dagger$ Arithmetic mean $( \pm 1 \mathrm{SE})$ of three separate experiments in which a total of eleven mice were tested.

$\ddagger$ Arithmetic mean $( \pm 1 \mathrm{SE})$ of eleven individually assayed mice in three separate experiments.

splenic CFU-s content observed in $+/+$ littermates, showed a comparable rise in cellularity and CFU-s numbers. A maximal stimulating effect was found using $100 \mu \mathrm{g}$ of LPS. These observations indicate that LPS changes the proliferative status of CFU-s in the spleen (McCulloch et al., 1970) of $+/+$ and $\mathrm{Sl}^{\mathrm{j}} /+$ mice to a similar extent.

\section{Quantification of stem-cell activating factor (SAF) and splenic haemopoiesis stimulating factor (SHSF)}

The 4-day survival of normal $+/+$ CFU-s in a serum-free suspension culture was negligible (Table 4). In the presence of $10 \mu \mathrm{l}$ of SAF, the CFU-s recovery exceeded that of the inoculum 
Table 4. Effects of serum from normal or LPS-W injected $129 \mathrm{Sl}^{\mathrm{j}} /+$ or $+1+$ mice on CFU-s proliferation in vitro

\begin{tabular}{|c|c|c|}
\hline \multirow{2}{*}{$\begin{array}{l}\text { Serum } \\
\text { added* }^{*}\end{array}$} & \multicolumn{2}{|c|}{ CFU-s recovery (\% inoculum) } \\
\hline & Exp. I & Exp. II \\
\hline None & 0 & \\
\hline $\mathrm{SAF}^{+}$ & $131.3(3.5) \ddagger$ & n.d. \\
\hline$+1+$ NMS & 0 & 0 \\
\hline$+1+$ PLPSS & $78 \cdot 3(8 \cdot 7)$ & $68.7(10 \cdot 1)$ \\
\hline $\mathrm{S}^{\mathrm{j}} /+\mathrm{NMS}$ & 0 & 0 \\
\hline $\mathrm{Sl}^{\mathrm{j}} /+$ PLPSS & $79 \cdot 8(7 \cdot 1)$ & $56 \cdot 5(9.3)$ \\
\hline
\end{tabular}

- $50 \mu$ l of normal mouse serum (NMS) or postLPS-W serum (PLPSS) was added to $1 \mathrm{ml}$ of otherwise serum-free culture medium. Cultures were in duplicate.

$+10 \mu l$ of stage III MSCM instead of serum was added.

$\mp$ Arithmetic mean $( \pm 1$ SE) of spleen colony assay on ten mice.

value. The addition of NMS from both $+/+$ and $\mathrm{SI}^{\mathrm{j}} /+$ mice did not enhance CFU-s survival. However, PLPSS from $+/+$ and $\mathrm{Sl}^{\mathrm{j}} /+$ mice were similarly effective in activating CFU-s proliferation in vitro.

In contrast to the inactivity of NMS in vitro, in vivo administration induced a significant rise in splenic CFU-s numbers in both $+/+$ and $\mathrm{Sl}^{j} /+$ recipient mice (Table 5). Contrary to the significantly lower activity of $\mathrm{Sl}^{\mathrm{j}} /+\mathrm{NMS}$ as compared to $+1+\mathrm{NMS}, \mathrm{Sl}^{\mathrm{j}} /+\mathrm{PLPSS}$ induced a larger splenic CFU-S accumulation in recipient mice than $+/+$ PLPSS. These observations demonstrate that there is no deficiency of SHSF production in $\mathrm{Sl}^{\mathrm{j}} /+$ mice

Table 5. Effects of serum from normal LPS-Winjected $129 \mathrm{Sl}^{\mathrm{i}} /+$ or $+/+$ mice on spleen CFU-s levels in $\mathrm{Sl}^{\mathrm{j}} /+$ and $+/+$ mice

\begin{tabular}{|c|c|c|}
\hline \multirow{2}{*}{$\begin{array}{c}\text { Serum } \\
\text { injected* }\end{array}$} & \multicolumn{2}{|c|}{ Splenic CFU-s content $\left(\times 10^{3}\right)$} \\
\hline & $+1+$ mice & $\mathrm{SI}^{\mathrm{j} /+ \text { mice }}$ \\
\hline None & $4 \cdot 2(1 \cdot 1) \dagger$ & $1.8(0.5)$ \\
\hline BSS & $7.0(1.7)$ & $4.3(0.5)$ \\
\hline$+1+$ NMS & $12.7(1.4)$ & $5.3(0.8)$ \\
\hline$+/+$ PLPSS & $28 \cdot 1(4 \cdot 3)$ & $23.7(5.9)$ \\
\hline S $1^{j} /+$ NMS & $8 \cdot 1(0.4)$ & $2.5(0.7)$ \\
\hline Sl ${ }^{j} /+$ PLPSS & $49.8(4.9)$ & $35.6(5.9)$ \\
\hline
\end{tabular}

* $0.3 \mathrm{ml}$ of serum or BSS was injected i.p. Mice were killed at day 4. NMS, normal mouse serum; PLPSS, post-LPS-W serum; BSS, buffered saline solution.

+ Arithmetic mean $( \pm 1 \mathrm{SE})$ of three individually assayed mice. 
following treatment with LPS. Furthermore, $\mathrm{Sl}^{\mathrm{j}} /+$ mice have an excellent response to SHSF contained in injected serum (Table 5). Analysis of PLPSS by the Limulus amoebocyte lysate assay indicated the presence of $0.1 \mu \mathrm{g}$ of LPS per ml of PLPSS. This amount of LPS could not have led to the observed increases in splenic CFU-s numbers.

\section{DISCUSSION}

The objective of the experiments reported in this paper was to investigate the control of CFU-s proliferation in microenvironmentally defective $\mathrm{Sl}^{\mathrm{j}} /+$ mice and in their normal $+/+$ littermates. We have previously shown that treatment with LPS can be used as a probe to reveal defective splenic stromal support for CFU-s proliferation (Ploemacher et al., 1983a,b). Thus $\mathrm{Sl} / \mathrm{Sl}^{\mathrm{d}}$ mice, as well as reconstituted irradiated normal mice, demonstrated a deficient splenic CFU-s and a haemopoietic progenitor cell accumulation in response to LPS. We now show that $\mathrm{Sl}^{\mathrm{j}} /+$ mice, which have a significantly reduced splenic CFU-s number when compared with their normal $+/+$ littermates, are able to mount a relatively normal splenic CFU-s increase in response to treatment with LPS. Similarly, CFU-s, BFU-e and CFU-G/M exhibited normal repopulation kinetics after TBI and $+/+$ bone-marrow cell (BMC) grafting in $\mathrm{Sl}^{\mathrm{j}} /+$ haemopoietic organs. However, $+/+\mathrm{BMC}$ formed fewer macroscopic colonies in $\mathrm{Sl}^{\mathrm{j}} /+$ spleens when measured on days 7 and 10 , while progenitor cell accumulation was normal and CFU-s renewal was even higher in $\mathrm{Sl}^{\mathrm{j}} /+$ spleen colonies than in $+/+$ spleen colonies. The reduction of the microscopic colony number detected on day 7 was not present on day 10. This observation indicates that about $35 \%$ of all microscopic colonies that were observed on day 10 were not detectable on day 7 and therefore had undergone a severely delayed development or restricted proliferation. In view of this, we propose that the $\mathrm{Si}^{\mathrm{j}} /+$ splenic niches for macroscopic colony formation are deficient in number but not in quality. In addition, one-third of all niches is qualitatively deficient and only supports microscopic colony formation over a 10-day period. The data in Tables 1 and 2 suggest that these microscopic colonies contain fewer CFU-s when determined on day 10. Since the differential colony counts (Table 2) did not reveal a preponderance of undifferentiated or early erythroid (EI) colonies in $\mathrm{Sl}^{\mathrm{j}} /$ + spleens on day 10, it is also implied that the small microscopic colonies were not delayed in their differentiation, but had undergone limited proliferation, and therefore were too small to be detected at day 7 . It should be noted that the term 'niche' is not used here as qualified by Schofield (1978) who characterized it as a site in which stem cells are not susceptible to differentiating stimuli.

We have presented evidence that $\mathrm{Sl}^{\mathrm{j}} /+$ mice, in contrast with previous reports on $\mathrm{Sl} / \mathrm{Sl}^{d}$ mice (McCulloch et al., 1970; Ploemacher et al., 1983a) are able to respond to LPS injection with a splenic CFU-s accumulation comparable to $+/+$ mice. Bacterial LPS elicits a rise in serum SHSF levels (Staber \& Metcalf, 1980). We have previously demonstrated that an activity, present in post-LPS serum, triggers CFU-s to proliferate in vitro, in addition to the in vivo active SHSF (Ploemacher et al., 1983a). This stem-cell activating factor (SAF) has been operationally equated with SHSF in this work. The observation that the SAF level was not different in PLPSS derived from $+/+$ and $\mathrm{Sl}^{\mathrm{j}} /+$ mice, whereas the SHSF level was $1 \cdot 5-2 \cdot 0$ times higher in $\mathrm{Sl}^{j} /+$ PLPSS than in $+1+$ PLPSS, suggests that these two biological activities may be produced by different substances. We have shown that $\mathrm{Sl}^{\mathrm{j}} /+$ mice, similar to $\mathrm{Sl} / \mathrm{Sl}^{\mathrm{d}}$ mice (Ploemacher et al., 1983a), respond to LPS with normal production of humoral CFU-s proliferation regulators. However, in contrast with $\mathrm{Sl}^{\mathrm{j}} /+$ mice, the splenic stroma of $\mathrm{Sl} / \mathrm{Sl} l^{d}$ mice is unable to provide sufficient support for the proliferation and differentiation of CFU-s (McCulloch et al., 1965, 1970; Ploemacher et al., 1983a) and for macroscopic spleen colony 
formation (Altus et al., 1971). An interesting observation in this respect is that of Wolf (1974), who studied the development of spleen colonies in $900 \mathrm{R}$ irradiated $\mathrm{Sl} / \mathrm{Sl}^{\mathrm{d}}$ and $+/+$ mice at 8 days following injection with $5 \times 10^{4}+1+\mathrm{BMC}$. The $+1+$ animals were found to have developed the expected number of macroscopic colonies, whereas the $\mathrm{Sl} / \mathrm{Sl}^{\mathrm{d}}$ mice developed none. However, upon careful inspection of subserial histologic sections, it was seen that many small haematopoietic colonies had developed, totalling one-third of the microscopic colony number in $+/+$ spleens. These observations suggest that $\mathrm{Sl} / \mathrm{Sl}^{\mathrm{d}}$ mice not only have a quantitative deficiency of niches for colony formation, but also suffer from a qualitative defect of the remaining niches, leading to diminished proliferation of CFU-s and their progeny in any one colony. If this were true, the expression of the $\mathrm{Sl}^{\mathrm{j}} /+$ genotype on the level of CFU-s proliferation would qualitatively differ from that of the $\mathrm{Sl} / \mathrm{Sl}^{\mathrm{d}}$ allele combination.

\section{ACKNOWLEDGMENTS}

We would like to thank Professor Dr O. Vos for critically reviewing this manuscript, and Mrs C. Meijerink-Clerkx for typing the manuscript.

This investigation is supported by a programme grant of the Netherlands Foundation for Medical Research (FUNGO) and the Queen Wilhelmina Fund.

\section{REFERENCES}

Altus, M.S., Bernstein, S.E., Russel, E.S., Carsten, A.L. \& Upton, A.C. (1971) Defect extrinsic to stem cells in spleens of steel anemic mice. PSEBM 138, 985.

Brockbank, K.G.M. \& Ploemacher, R.E. (1983) Quantitation of stromal and hemopoietic progenitors in spleen and femoral marrow derived from steel $\left(\mathrm{Sl} /+\right.$ and $\left.\mathrm{Sl} / \mathrm{Sl}^{\mathrm{d}}\right)$ mice and their normal littermates. Exp. Hemat. 11 , 467.

Cerny, J., Waner, E.B. \& Rubin, A.S. (1975) T cell products activating stem cells: further studies on the origin and action of the factor(s). J. Immunol. $115,513$.

Cole, R.J., Tarbut, R.G., Cheek, E.M. \& White, S.L. (1974) Expression of congenital defects in the haemopoietic microenvironment: pre-natal erythropoiesis in anaemic 'steel' ( $\left.\mathrm{Sl}^{\mathrm{j}} / \mathrm{Sl}^{\mathrm{j}}\right)$ mice. Cell Tissue Kinet. 7,463 .

Dicke, K.A., VAN Den ENGh, G.J. \& Lowenberg, B. (1974) The behaviour of the hemopoietic stem cell in various culture systems. In: Second Workshop on Hemopoiesis in Culture, Airline House, Virginia, May 23-26, 1973, (ed. W.A. Robinson), p. 31. U.S. Government Printing Office, Washington DC, U.S.A.

Levin, J., Poore, T.E., ZANger, N.P. \& OSER, R.S. (1970) Detection of endotoxin in the blood of patients with sepsis due to gram-negative bacteria. New Engl. J. Med. 283, 1313.

LöWENBERG, B. \& DiCKE, K.A. (1977) Induction of proliferation of hemopoietic stem cells in culture. Exp. Hemat. 5, 319.

McCulloch, E.A., Siminovitch, L., Till, J.E., Russell, E.S. \& Bernstein S.E. (1965) The cellular basis of the genetically determined hemopoietic defect in anemic mice of genotype SI/SI ${ }^{d}$. Blood, 26, 399.

McCulloch, E.A., Thompson, M.W., SiminovitCH, L. \& Till, J.E. (1970) Effects of bacterial endotoxin on haemopoietic colony-forming cells in the spleens of normal mice and mice of genotype $\mathrm{Sl} / \mathrm{Sl}]^{\mathrm{d}}$. Cell Tissue Kinet. 3. 47.

Mintz, B. \& Cronmiller, C. (1978) Normal blood cells of anemia genotype in teratocarcinoma-derived mosaic mice. Proc. Natl Acad. Sci. U.S.A. 75, 6247.

Ploemacher, R.E., Brockbank, K.G.M., Brons, N.H.C. \& DE Ruiter, H. (1983b) Latent sustained injury of murine hemopoietic organ stroma induced by ionizing irradiation. Haematologica, 68, 454.

Ploemacher, R.E. \& Brons. N.H.C. (1984) Characteristics of the CFU-s population in mice carying the $\mathrm{Sl}^{\mathrm{j}}$ allele. Cell Tissue Kinet. 17, 1.

Ploemacher, R.E., Molendijk, W.J., Brons, N.H.C. \& De Ruiter, H. (1983a) Defective support of Sl/Sl ${ }^{d}$ splenic stroma to humoral regulation of stem cell proliferation. (Submitted for publication.)

SCHOfiELD, R. (1978) The relationship between the spleen colony-forming cell and the haemopoietic stem cell: a hypothesis. Blood Cells, $4,7$. 
Siminovitch, L., Till, J.E. \& MCCulloch, E.A. (1964) Decline in colony forming ability of marrow cells subjected to serial transplantation into irradiated mice. J. Cell. Comp. Physiol. 64, 23.

Staber, F.G. \& Metcalf, D. (1980) Humoral regulation of splenic hemopoiesis in mice. Exp. Hemat. 8, 1094.

TILL, J.E. \& MCCULLOCH, E.A. (1961) A direct measurement of the radiation sensitivity of normal bone marrow cells. Rad. Res. 14, 213.

Vos, O., Buvrman, W.A. \& Ploemacher, R.E. (1972) Mobilization of haemopoietic stem cells (CFU) into the peripheral blood of the mouse; effects of endotoxin and other compounds. Cell Tissue Kinet. 5, 467.

Wagemaker, G., Merchav, S. \& Burger, G. (1982) Multiplication of pluripotent stem cells induced by purified stem cell activating factor (SAF) in serum free suspension cultures. Exp. Hemat. 10 (Suppl. 1), 162.

Wagemaker, G., Merchav, S. \& Burger, G. (1982) Multiplication of pluripotent stem cells induced by purified stem cell activating factor (SAF) in serum free suspension cultures. Exp. Hemat. 10 (Suppl. 11), 162. 